\title{
Immunomodulatory effects of Ziziphora tenuior L. extract on the dendritic cells
}

\author{
Abbas Azadmehr ${ }^{1}$, Robabeh latifi ${ }^{2}$, Sahar Mosalla ${ }^{2}$, Reza Hajiaghaee ${ }^{3}$ and Mojtaba Shahnazi ${ }^{*}$
}

\begin{abstract}
Background: Ziziphora tenuior L. (Kakuti in Persian) is used in traditional medicine for treatment of gastrointestinal disorders as carminative and analgesic plant. The other usages of this plant are included treatment of diarrhea and nausea. Therefore in the present study we evaluated the immunomodulatory effects of the ethanolic extract of this plant on the dendritic cells (DCs).

Results: Ziziphora tenuior L. extract significantly $(p=0.002)$ increased the level of surface expression of CD40 as an important co-stimulatory marker on DCs compared to the control. However this extract did not change CD86 and MHC-II molecules, so it could promote DCs phenotypic maturation. Treatment of DCs with the extract resulted in slightly increased of the production of (IL-12); however, this change was not significant. In addition, the ability of treated DCs to stimulate allogenic T cells proliferation and cytokines secretion was examined in the co-cuture of these cells with T cells in mixed lymphocyte reaction (MLR). Z. tenuior L. at the $100 \mu \mathrm{g} / \mathrm{ml}$ concentration inhibited the proliferation of allogenic T cells and also significantly $(P<0.001)$ increased the level of IL-10. Moreover, the extract at 10-100 $\mathrm{\mu g} / \mathrm{ml}$ concentration caused slightly increase in IFN- $\gamma$ production and decreased IL-4 cytokines but these changes were not significant.

Conclusions: These findings indicated that $Z$. tenuior $\mathrm{L}$. extract can modulate immune response by induction of CD40 expression on DCs and cytokine production; whereas it can inhibit T cell stimulating activity of DCs in high concentration. These findings possibly in part explain the traditional use of this plant in treatment of immune-mediated disorders. However future studies are needed.
\end{abstract}

Keywords: Ziziphora tenuior L, Immunomodulation, Dendritic cells, T cell responses, Cytokine

\section{Introduction}

Medicinal plants are used to treat immune disorders, such as inflammatory and autoimmune diseases in the worldwide. Previous studies showed that some herbal medicine have immunomodulatory effects [1,2]. Ziziphora genus (Lamiacaea) is included of four species namely $Z$. tenuior L., Z.capitata L., Z.clinopodioides and Z. Persica Bunge [3]. Ziziphora or Kakuti in Iranian traditional medicine is recognized to dried aerial parts of $Z$. tenuior L. which contains at least $1.2 \%$ (volum/weight) of the essential oil [4]. This medicinal plant distributed widely in Iran, Pakistan, Turkmenistan, Afghanistan, Armenia, Anatolia, Syria, Transcaucasia and Central Asia [3]. In traditional medicine, Ziziphora is used to treat dysentery, fever, uterus infection and also as analgesic plant [5]. In addition, it is

\footnotetext{
* Correspondence: shahnazi58@yahoo.com

2Parasitology Department, Qazvin University of Medical Sciences, Qazvin, Iran Full list of author information is available at the end of the article
}

used in the treatment of the gastrointestinal disorder as carminative or treat of vomiting or diarrhea [6,7]. Phytochemical analysis indicated that major components of its essential oil are pulegone, isomenthone, thymol, menthone and piperitone [7-10]. Previous studies showed that these compounds are suggested to be responsible for the mentiond medicinal properties. It has been shown that, Ziziphora clinopoides methanolic extract inhibited inflammatory mediators in dextran sodium sulfate induced colitis in mice and also protected acetic acidinduced toxic bowel inflammation through reduction of cellular lipid peroxidation and myeloperoxidase activity $[11,12]$. On the other hand, Dendritic cells are potential antigen presenting cells for naive T cells and act as a link between the acquired and innate immune systems for the initiation of the protective immune response or the induction of immune tolerance [13]. Maturation status, origin and phenotype are affected on the function of 
these cells [14]. The nature of the cytokines produced by DCs in response to various ligands eventually modulates and determines the type of Th cell response. DCs have the exclusive ability to stimulate naive $\mathrm{T}$ cells to either Th1 or Th2 cells and also effectively down-regulate $\mathrm{T}$-cell responses through the generation of $\mathrm{T}$ regulatory cells $[15,16]$. It has been demonstrated that immature DCs can effectively present antigen to naive $T$ cells but because of low expression of co-stimulatory molecules such as CD40, CD86 and MHC II they cannot suitably stimulate immune system, finally $\mathrm{T}$ cells activation and proliferation are inhibited [14]. In this regards, maturation of DCs converts them to the cells that can stimulate immune system. So, the use of these cells as therapeutic targets by pharmacological compounds such as medicinal plant is a valuable strategy to modulate immune responses. In the present study we have evaluated the immunomodulatory effects of $Z$. tenuior L. extract on the function and maturation of DCs.

\section{Materials and methods \\ Animals}

The male BALB/c and C57BL/6 mice with 6-8 week old were purchased from Razi Institute (Karaj, Iran) and were kept under optimal conditions of hygiene and received standard mouse chow and water ad libitum. In this study, all experimental procedures on handling the animals were approved by the ethical committee of Qazvin University of Medical Sciences.

\section{Preparation of DCs from mice spleen}

To isolate DCs from spleen, the mice CD11c ${ }^{+}$isolation kit (Miltenyi Biotech, Germany), was used as described in previous study [17]. Briefly, the mice spleens were isolated and minced to very small pieces and then suspended in cold $\left(4^{\circ} \mathrm{C}\right)$ PBS containing $1.2 \mathrm{mg} / \mathrm{ml}$ collagenase D (Roche, Germany).The cell suspension, incubated at $37^{\circ} \mathrm{C}$ for 40 minutes and was passed through a cell mesh and the collected cells were washed twice. Then, mononuclear cells (MNC) were separated by Nycodenz (Axis-shield, Norway); a material used in density gradient cell separation techniques. According to the manufacturer's protocol, anti-CD11c magnetic beads (Miltenyi Biotech, Germany) were added to the cells and incubated at $4^{\circ} \mathrm{C}$ for 30 minutes and the non-bonded antibodies were washed out. Using of the minimacs separator (MS) cell columns into the magnetic field (MS separation unit, Miltenyi Biotech, USA) and washed by $1.5 \mathrm{ml}$ EDTAcontaining PBS and then passed through the column to absorb the magnetic bead coated DCs and the unwanted cells were washed out using at least 3 washes of $500 \mu \mathrm{l}$ EDTA-containing PBS. The isolated DCs were collected by disconnecting the column from the magnetic field and injecting $1 \mathrm{ml}$ PBS-EDTA in it under pressure.
Purity of the CD11c dendritic cells was determined above $94 \%$ using flow cytometry.

\section{Plant material and preparation of the ethanolic extract} Ziziphora tenuior was purchased from herbal market and authenticated by a botanist. Voucher specimens were preserved in the central herbarium of medicinal plants (ACECR). The aerial parts of plant were air-dried at room temperature. This was ground in to powder. The aerial part of plant (50 g) was extracted using percolation method by ethanol (80\%) at room temperature. Solvent was completely removed by drying under reduced pressure at $40^{\circ} \mathrm{C}$ in a rotary evaporator. The samples were stored at $4^{\circ} \mathrm{C}$ until use (3 g, $6 \%$ yield) [18].

\section{Effect of extract on DCs viability}

To determine, the effect of cytotoxic concentration of the extract on DCs, 3-(4, 5-dimethylthiazol-2-yl)-2, 5-diphenyltetrazolium bromide (MTT) colorimetric assay was used [15]. Briefly, dendritic cells $\left(10^{5}\right.$ cells/well) were treated with $Z$. tenuior L. extract at 10 to $200 \mu \mathrm{g} / \mathrm{ml}$ concentrations in the cell culture plates for $24 \mathrm{~h}$, and then $10 \mu \mathrm{l} \mathrm{MTT} \mathrm{(5} \mathrm{mg/ml,} \mathrm{Sigma)} \mathrm{was} \mathrm{added} \mathrm{to} \mathrm{each} \mathrm{well} \mathrm{and}$ cells were incubated for an additional $4 \mathrm{~h}$ at $37^{\circ} \mathrm{C}$. Dimethyl sulphoxide (DMSO 0.1\%) as vehicle and lipopolysaccharides (LPS $1 \mu \mathrm{g} / \mathrm{ml}$ ) as DC maturation inducing agent, were used as negative and positive controls, respectively. Finally, the optical density (OD) of each well was measured at 570 with reference at $630 \mathrm{~nm}$ on an enzyme-linked immuosorbent assay (ELISA) plate reader and the viability was determined as the follows: (OD of extract-treated cells/OD of DMSO-treated cells) $\times 100$.

\section{Analysis of markers expression of co-stimulatory molecules}

In order to evaluate the effect of $Z$. tenuior L. on the expression of co-stimulatory molecules, DCs were treated with the extract for $18 \mathrm{~h}$ and analyzed using flow cytometer (FACSCalibur, Beckton Dickinson Biosciences, San Jose, CA). The cells were stained with phycoerithrin (PE)-conjugated anti-CD11c, FITC-conjugated anti-CD86, fluorescence isothiocyanate (FITC)-conjugated anti-CD40, FITC-conjugated anti-MHC II antibody and appropriate conjugated isotypes (Beckton Dickinson (BD) Pharminogen, San Diego, CA). Finally, the percentage of markers expression on extract-treated DCs and DMSO-treated DCs was calculated and the mean florescent intensity (MFI) was analyzed using Win MDI software (Scripps, La Jolla, CA).

\section{Mixed lymphocyte reaction}

To determine the proliferative effect of $Z$. tenuior $\mathrm{L}$. extract-treated DCs on T lymphocytes, allogeneic mixed lymphocyte reaction (MLR) assay was used. Briefly, T cells 
were purified from lymph nodes of C57BL/6 mice using nylon wool. Then, $Z$. tenuior L -treated DCs from BALB/c mice were inactivated with mitomycin $C(0.5 \mathrm{mg} / \mathrm{ml})$ for $20 \mathrm{~min}$, and then cells were washed with phosphate buffered saline (PBS) for three times and resuspended in culture medium containing 10\% FCS. Mitomycin-treated DCs $\left(10^{4}\right.$ cells/well), as stimulator cells, co-cultured with $10^{5}$ allogenic $\mathrm{T}$ cells, as responder cells, in a 96-well culture plate (Nunc, Denmark) in triplicates for $48 \mathrm{~h}$. As negative control, a triplicate wells containing DMSOtreated DCs plus allogenic T cells were used. Finally, T cell proliferation was measured by a 5-Bromo-20-deoxyuridine (BrdU) cell proliferation assay kit (Roche, Germany) according to the manufacturer's instructions. The result was concluded as the follows: (OD of extract-treated culture/OD of DMSO-treated culture) $\times 100$.

\section{Effect of the extract on the cytokines production}

In order to evaluate immunomodulatory effect of $Z$. tenuior L. extract on the cytokines production, the enzyme-linked immunosorbent assay (ELISA) method was used. Briefly, the supernatant of extract-treated DCs and MLR cultures were collected and used to measure IFN- $\gamma$, IL-4, IL-12 and IL-10 by ELISA kits according to the manufacturer's protocol (eBioscience, USA), respectively.

\section{Statistics analysis}

In this study, all data were representative of at least three independent experiments performed in triplicate and presented as mean \pm standard deviation (SD). MannWhitney test and one-way analysis of variance (ANOVA) were used for the evaluation of statistical differences between the results and $\mathrm{p}$ vales less than 0.05 were considered significant.

\section{Results}

Viability of DCs after exposure with $Z$. tenuior L. extract The DCs viability was determined using MTT assay. For this purpose, these cells were treated with different concentrations of the plant extract for $24 \mathrm{~h}$. Our results indicated that this extract at concentration of 10, 50 and $100 \mu \mathrm{g} / \mathrm{ml}$ had no cytotoxic effect on DCs (Figure 1) however the extract at $200 \mu \mathrm{g} / \mathrm{ml}$ had significantly $(\mathrm{P}<0.05)$ cytotoxic effect on DCs. Therefore these concentrations (10 to $100 \mu \mathrm{g} / \mathrm{ml}$ ) were used as safe dose of $Z$. tenuior L. extract for the next experiments on DCs.

\section{Effect of Z. tenuior L. extract on maturation phenotype of DCs}

We analyzed the percentage expression and fluorescent intensity of CD86, CD40 and MHC II co-stimulatory molecules on $Z$. tenuior L-treated DCs by flow cytometry. Our results showed that the extract modulate the percentage expression and fluorescent intensity of CD86,

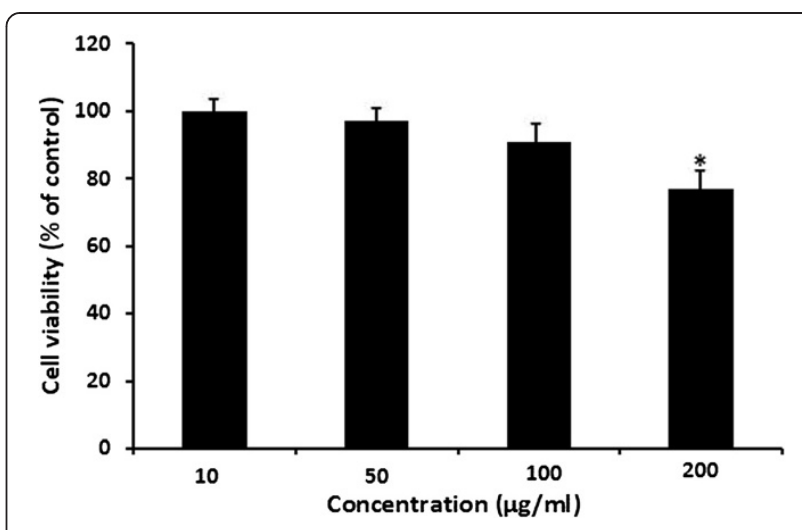

Figure 1 DCs viability after treatment with $Z$. tenuior L. extract. MTT assay was used for determining of DCs viability. These cells were treated with different concentrations of the plant extract for $24 \mathrm{~h}$. DCs treated with DMSO was used as control. The results show mean \pm standard deviation of three independent experiments performed in triplicate. The extract at 10 to $100 \mu \mathrm{g} / \mathrm{ml}$ had no significant growth inhibitory effects on DCs. *Significantly $(P<.0 .05)$ different was between the extract-treated cells and the control cells.

CD40 and MHC II molecules on DCs. As shown in Figure 2, this extract significantly $(P=0.002)$ increased the percentage expression of CD40 molecules at $100 \mu \mathrm{g} / \mathrm{ml}$ compared with negative control. Although, Z. tenuior L. Extract increased the percentage expression and fluorescent intensity of CD86 and MHC II on DCs but this effect was not significant comparing with control. These finding showed that $Z$. tenuior L. extract can modulate the maturation phenotype markers on DCs.

\section{Effect of $Z$. tenuior L. extract on allogenic MLR}

To determine the effects of the $Z$. tenuior $L$. extract on allogenic immune response and DCs function, the allogenic $\mathrm{T}$ cells from $\mathrm{C} 57 \mathrm{BL} / 6$ were co-cultured with DCs isolated from $\mathrm{BALB} / \mathrm{c}$ mice. For this purpose, the DCs were treated with concentrations of 10 to $100 \mu \mathrm{g} / \mathrm{ml}$ of the extract for $18 \mathrm{~h}$ and then cells were co-cultured with allogenic $\mathrm{T}$ cells in MLR assay. Finally, the proliferation of $\mathrm{T}$ lymphocytes was evaluated using BrdU incorporation assay. As it is shown in Figure 3, the Z. tenuior L. extract significantly $(\mathrm{p}<0.05)$ decreased the proliferation of $\mathrm{T}$ cells at $100 \mu \mathrm{g} / \mathrm{ml}$. The results indicated that the proliferation of these cells decreased to $76.8 \pm 3.4$ percent of control when DCs had been treated with $100 \mu \mathrm{g} / \mathrm{ml}$ of the extract concentration.

\section{Effect of Z. tenuior L. on the production of cytokines}

The concentration of the IL-12 cytokine in the supernatant of the extract-treated DCs was measured. As shown in Figure 4A, treatment of DCs with this extract at 10 to $100 \mu \mathrm{g} / \mathrm{ml}$ resulted in slightly increase of production of IL-12 by these cells comparing with the negative control. However this change was not significant. In 


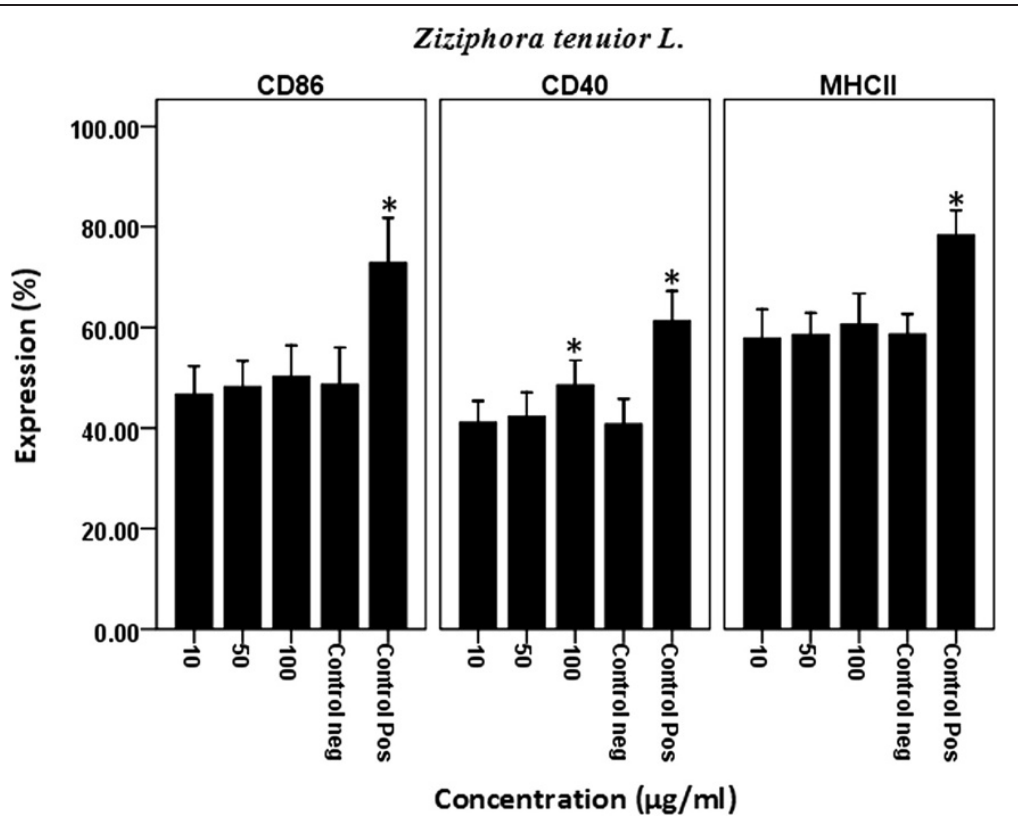

Figure 2 Effect of $Z$. tenuior L. extract on maturation phenotype of DCs. In order to determine the effect of $Z$. tenuior $L$. extract on maturation phenotype on DCs, these cell were treated with the extract for $18 \mathrm{~h}$ and then the expression of CD40, CD86 and MHC II molecules was determined by flow cytomety. DC treated with DMSO as negative control and also lipopolysaccharides (LPS $1 \mu \mathrm{g} / \mathrm{ml}$ ) as positive control were considered. The results show mean \pm standard deviation of three independent experiments performed in triplicate. ${ }^{*}$ Significantly $(P<0.05)$ different was between the extract-treated cells and the negative control cells.

addition, we measured the effect of the extract on IFN- $\gamma$, IL-4 and IL-10 production in MLR. We found that, the extract at $10-100 \mu \mathrm{g} / \mathrm{ml}$ concentrations slightly increased production of IFN- $\gamma$ and decreased IL-4 cytokines but these changes were not significant (Figure 4B, C). However, as it is shown in Figure 4D, our result indicated that

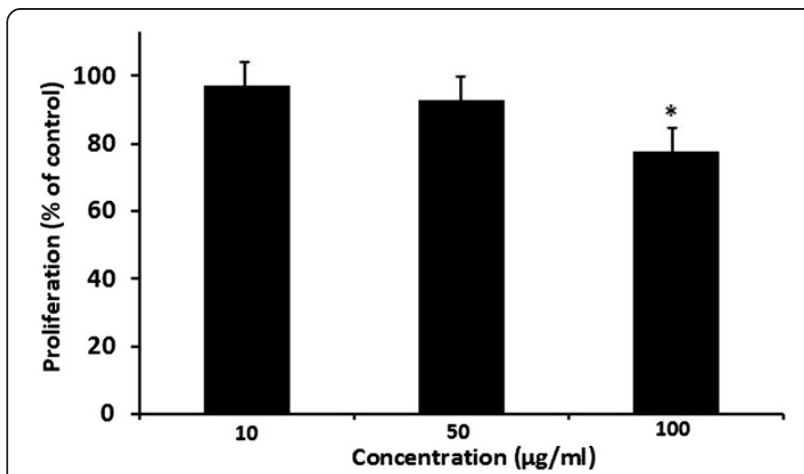

Figure 3 The effect of $Z$. tenuior L. extract on allogenic MLR. In order to find the effects of the $Z$. tenuior $L$. extract on allogenic immune response, DCs were treated with the extract for $18 \mathrm{~h}$ and then co-cultured with allogenic T cells for $48 \mathrm{~h}$. DMSO-treated DCs plus $T$ cells was considered as control. Brdu incorporation assay was used for measuring of cell proliferation. The results show mean \pm SD of the cell proliferation in the presence of the extract as compared to the proliferation of controls taken to be $100 \%$. Our results indicated that DCs treated with $100 \mu \mathrm{g} / \mathrm{ml}$ of extract significantly $\left.{ }^{*} \mathrm{P}<0.05\right)$ have decreased $\mathrm{T}$ cells proliferation. the Z. tenuior L. extract at $100 \mu \mathrm{g} / \mathrm{ml}$ concentration significantly $(\mathrm{p}<0.05)$ increased IL-10 cytokine production.

\section{Discussion}

In this study, we evaluated the immunomodulatory effects of $Z$. tenuior L. extract on the DCs. Several studies showed that natural agents such as plants can modulate DCs activity [19-21]. Dendritic cells are professional antigen presenting cells for naive $\mathrm{T}$ cells and act as a link between the acquired and innate immune systems for the initiation of the protective immune response or the induction of immune tolerance [13]. Therefore, to find out the new DCs immunomodulaters are considered as the important targets for immune response as well as immune regulation. Ziziphora is used to treat dysentery, fever, uterus infection and also analgesic plant in traditional medicine [5]. In addition, it is used in the treatment of the gastrointestinal disorder as carminative or treat of vomiting or diarrhea [6,7]. It has been shown that, Ziziphora clinopoides methanolic extract inhibited inflammatory mediators in dextran sodium sulfate induced colitis in mice and also protected acetic acid-induced toxic bowel inflammation through reduction of cellular lipid peroxidation and myeloperoxidase activity $[11,12]$.

In the present study, we examined the effect of the $Z$. tenuior L. extract on the phenotypic maturation and function of DCs. The expression of CD86, CD40 and MHC- II molecules are important co-stimulatory and maturation 

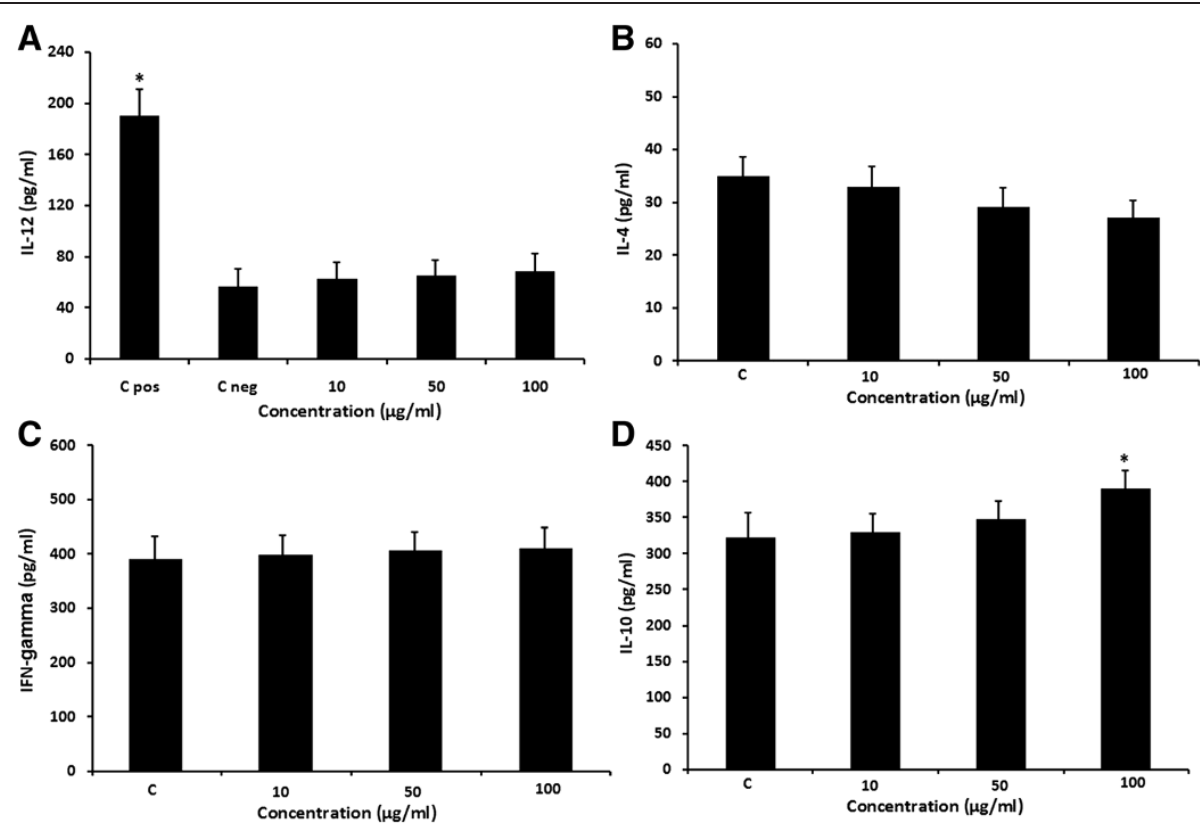

Figure 4 Effect of $Z$. tenuior L. extract on cytokine production. The effect of the $Z$. tenuior L. extract on IL-12 production by DCs after $18 \mathrm{~h}$ showed in Figure 4A. DMSO treated DCs as control negative (C neg) and LPS as positive control (C pos) were considered. Moreover, the effect of the extract on IFN- $y, I L-4$ and IL-10 production in MLR assay showed in Figure 4B, C and D. DMSO-treated DCs plus allogenic T cells as Control considered. ${ }^{*} P<0.05$ shows significant difference with the negative control.

markers on DCs and have critical roles in antigen presentation and $\mathrm{T}$ cell activation. Our results showed that the extract modulate the percentage expression and fluorescent intensity of CD86, CD40 and MHC II molecules on DCs. Previous studies indicated that some herbal extracts can modulate immune response by immunomodulatory effect on the CD40 expression on the dendritic cells $[22,23]$. Our results showed that the extract significantly increased the percentage expression of CD40 molecules at $100 \mu \mathrm{g} / \mathrm{ml}$ compared with control negative. Although, $Z$. tenuior L. extract increased the percentage expression and fluorescent intensity of CD86 and MHC II on DCs but this effect was not significant comparing with control. These finding indicated that $Z$. tenuior L. extract can modulate the maturation phenotype markers on DCs.

In addition, we evaluated the immunomodulatory effect of $Z$. tenuior $\mathrm{L}$. extract on the DCs functions by releasing of cytokines and MLR. IL-12 is a cytokine released by DCs which can induce differentiation of T cells to Th1 and cellular immunity, by contrast IL-10 is a Th1 inhibitory cytokine and also, IL-4 and IFN- $\gamma$ cytokines are landmark of deviation to Th1 or Th2 response [24]. Our results indicated that the treatment of DCs with this extract at 10 to $100 \mu \mathrm{g} / \mathrm{ml}$ concentration increased production of IL-12 comparing with the negative control however this change was not significant. Also, the extract at $10-100 \mu \mathrm{g} / \mathrm{ml}$ concentrations increased production of IFN- $\gamma$ and decreased IL-4 cytokines but these changes were not significant. However, our result indicated that the $Z$. tenuior L. extract at $100 \mu \mathrm{g} / \mathrm{ml}$ concentration significantly increased IL-10 cytokine production. We assumed that the increased IL-12 production by DCs using $10-100 \mu \mathrm{g} / \mathrm{ml}$ extract concentration along with production of more IFN $-\gamma$ and less IL-4 by T cells in MLR suggest the ability of $Z$. tenuior $\mathrm{L}$. extract to deviate the cytokine pattern of $\mathrm{T}$ cells toward a Th1 response. However, the extract at $100 \mu \mathrm{g} / \mathrm{ml}$ concentration has increased IL-10 secretion in MLR and also reduced the proliferation of T cells in allogenic response, which indicated the inhibitory effect of the extract at higher concentration on the immune response. Moreover, the difference between the effects of the extract at higher concentrations may be attributed to the presence of various constituents in the extract with different mode of actions. So, to confirm Th1/Th2 polarization in co-culture of $\mathrm{T}$ cells with $Z$. tenuior $\mathrm{L}$. treated-DCs, study of the $T$ cell signaling activity of DCs and the expression of T bet and GATA-3 as related transcription factors for Th1 and Th2 differentiation is recommended [25]. Future studies are suggested for identifying the main bioactive compound of this plant and other immunomodulatory mechanisms.

\section{Conclusions}

Our findings indicated that $Z$. tenuior L. extract can modulate immune response by induction of CD40 expression on DCs and cytokine production; whereas it can inhibit $\mathrm{T}$ cell stimulating activity of DCs in high concentration. These findings possibly in part explain 
the traditional use of this plant in treatment of immunemediated disorders. However future in vitro and in vivo studies are needed.

\section{Competing interests}

The authors declare that they have no competing interests.

\section{Authors' contributions}

AA designed and supervised the study and wrote the manuscript. $\mathrm{RH}$ provided plant materials. RL and SM carried out the experiments. MSh supervised the study. All authors read and approved the final manuscript.

\section{Acknowledgement}

We would like to thank of the Cellular and Molecular Research Center of the Research Vice-Chancellor of Qazvin University of Medical Sciences for financial support and also, the Medicinal Plants Research Center, Institute of Medicinal Plants, (ACECR), Karaj, Iran. This manuscript was a part of thesis for receiving the degree of MSc in medical parasitology in the Qazvin University of Medical Sciences, Qazvin, Iran.

\section{Author details}

'Immunology Department, Qazvin University of Medical Sciences, Qazvin, Iran. ${ }^{2}$ Parasitology Department, Qazvin University of Medical Sciences, Qazvin, Iran. ${ }^{3}$ Pharmacognosy and Pharmaceutics department of Medicinal Plants Research Center, Institute of Medicinal Plants, (ACECR), Karaj, Iran.

Received: 20 April 2014 Accepted: 2 September 2014

Published online: 17 September 2014

\section{References}

1. Su CA, Xu XY, Liu DY, Wu M, Zeng FQ, Zeng MY, Wei W, Jiang N, Luo X: Isolation and characterization of exopolysaccharide with immunomodulatory activity from fermentation broth of Morchella conica. Daru 2013, 21(1):5.

2. Azadmehr A, Hajiaghaee R, Zohal MA, Maliji G: Protective effects of Scrophularia striata in Ovalbumin-induced mice asthma model. Daru 2013, 21(1):56

3. Zohrabi M: Investigation Botany, Microscopy, Analysis and Indicated Composition of Ziziphora Clinopodioides Subsp. Tehran: Tehran University; 2000.

4. Davis NC, Newland RC: The reporting of colorectal cancer: the Australian clinico-pathological staging system. Aust N Z J Surg 1982, 52(4):395-397.

5. Naeini A, Khosravi AR, Chitsaz M, Shokri H, Kamlnejad M: Anti-Candida albicans activity of some Iranian plants used in traditional medicine. J Med Mycol 2009, 19(3):168-172.

6. Naghibi F, Mosaddegh M, Mohammadi Motamed M, Ghorbani A: Labiatae Family in Folk Medicine in Iran: from Ethnobotany to Pharmacology. Pharm Res: Iran J; 2010:63-79.

7. Zargari A: Iranian Medicinal Plants. Tehran, IR Iran: Tehran university press; 1987.

8. Sezik E, Tümen G, Bașer KHC: Ziziphora tenuior L., a new source of pulegone. Flavour Fragrance J 1991, 6(1):101-103.

9. Kasumov FY: Component compositions of the essential oils of some species of the Genus Thymus. Chem Nat Comp 1987, 23(5):637-638.

10. de Sousa DP, Junior EV, Oliveira FS, de Almeida RN, Nunes XP, Barbosa-Filho $J M$ : Antinociceptive activity of structural analogues of rotundifolone: structure-activity relationship. Z Naturforsch C 2007, 62(1-2):39-42.

11. Amini-Shirazi N, Hoseini A, Ranjbar A, Mohammadirad A, Khoshakhlagh P, Yasa N, Abdollahi M: Inhibition of tumor necrosis factor and nitrosative/ oxidative stresses by Ziziphora clinopoides (Kahlioti); a molecular mechanism of protection against dextran sodium sulfate-induced colitis in mice. Toxicol Mech Methods 2009, 19(2):183-189.

12. Ghafari H, Yasa N, Mohammadirad A, Dehghan G, Zamani MJ, Nikfar S, Khorasani R, Minaie B, Abdollahi M: Protection by Ziziphora clinopoides of acetic acid-induced toxic bowel inflammation through reduction of cellular lipid peroxidation and myeloperoxidase activity. Hum Exp Toxicol 2006, 25(6):325-332.

13. Schuurhuis DH, Fu N, Ossendorp F, Melief CJ: Ins and outs of dendritic cells. Int Arch Allergy Immunol 2006, 140:53-72.

14. Reis E, Sousa C: Dendritic cells in a mature age. Nat Rev Immunol 2006, 6:476-483.
15. Gao Y, Nish SA, Jiang R, Hou L, Licona-Limón P, Weinstein JS, Zhao H, Medzhitov R: Control of T helper 2 responses by transcription factor IRF4-dependent dendritic cells. Immunity 2013, 17:722-732.

16. Min WP, Zhou D, Ichim TE, Strejan GH, Xia X, Yang J, Huang X, Garcia B, White $D$, Dutartre $P$, Jevnikar AM, Zhong R: Inhibitory feedback loop between tolerogenic dendritic cells and regulatory T cells in transplant tolerance. J Immunol 2003, 1:1304-1312.

17. Eftekharian MM, Zarnani AH, Moazzeni SM: In vivo effects of calcitriol on phenotypic and functional properties of dendritic cells. Iran J Immunol 2010, 7(2):74-82.

18. Hajiaghaee R, Monsef-Esfahani HR, Khorramizadeh MR, Saadat F, Shahverdi AR, Attar F: Inhibitory effect of aerial parts of Scrophularia striata on matrix metalloproteinases expression. Phytother Res 2007, 21(12):1127-1129.

19. Amirghofran Z, Bahmani M, Azadmehr A, Javidnia K, Miri R: Immunomodulatory activities of various medicinal plant extracts: effects on human lymphocytes apoptosis. Immunol Invest 2009, 38(2):181-192.

20. Azadmehr A, Afshari A, Baradaran B, Hajiaghaee R, Rezazadeh S, Monsef-Esfahani H: Suppression of nitric oxide production in activated murine peritoneal macrophages in vitro and ex vivo by Scrophularia striata ethanolic extract. J Ethnopharmacol 2009, 124(1):166-169.

21. Ghafourian Boroujerdnia M, Azemi ME, Hemmati AA, Taghian A, Azadmehr A: Immunomodulatory effects of Astragalus gypsicolus hydroalcoholic extract in ovalbumin-induced allergic mice model. Iran J Allergy Asthma Immuno 2011, 10(4):281-288.

22. Amirghofran $\mathrm{Z}$, Ahmadi $\mathrm{H}$, Karimi MH: Immunomodulatory activity of the water extract of Thymus vulgaris, Thymus daenensis, and Zataria multiflora on dendritic cells and T cells responses. J Immunoassay Immunochem 2012, 33(4):388-402.

23. Elluru SR, Duong van Huyen JP, Delignat $S$, Kazatchkine MD, Friboulet A, Kaveri SV, Bayry J: Induction of maturation and activation of human dendritic cells: a mechanism underlying the beneficial effect of Viscum album as complimentary therapy in cancer. BMC Cancer 2008, 8:161.

24. Ho CY, Lau CB, Kim CF, Leung KN, Fung KP, Tse TF, Chan HH, Chow MS: Differential effect of Coriolus versicolor (Yunzhi) extract on cytokine production by murine lymphocytes in vitro. Int Immunopharmacol 2004, 4:1549-1557.

25. Kang H, Oh YJ, Choi HY, Ham IH, Bae HS, Kim SH, Ahn KS: Immunomodulatory effect of Schizonepeta tenuifolia water extract on mouse Th1/Th2 cytokine production in-vivo and in-vitro. J Pharm Pharmacol 2008, 60:901-907.

\section{doi:10.1186/s40199-014-0063-8}

Cite this article as: Azadmehr et al:: Immunomodulatory effects of Ziziphora tenuior $\mathrm{L}$. extract on the dendritic cells. DARU Journal of Pharmaceutical Sciences 2014 22:63.

\section{Submit your next manuscript to BioMed Central and take full advantage of:}

- Convenient online submission

- Thorough peer review

- No space constraints or color figure charges

- Immediate publication on acceptance

- Inclusion in PubMed, CAS, Scopus and Google Scholar

- Research which is freely available for redistribution 